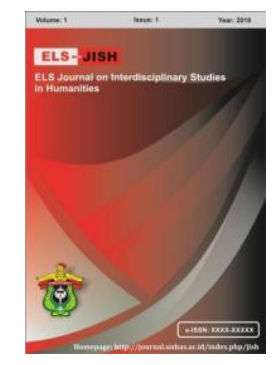

ELS-JISH

ELS Journal on Interdisciplinary Studies on Humanities

Volume 3 Issue 4, 2020

ISSN (print) : 2621-0843

ISSN (online) : 2621-0835

Homepage : http://journal.unhas.ac.id/index.php/jish

\title{
A Descriptive Qualitative Research: Islamic Values in Mandarese Oral Literature (Kalindaqdaq Masaala)
}

\author{
Rina Marliana ${ }^{1^{*}}$, AchmadTaqlidul Chair Fachruddin ${ }^{2}$ \\ ํrinamarliana@stainmajene.ac.id
}

\begin{abstract}
Kalindaqdaq is a famous oral literature in Mandarese Community in West Sulawesi. This research focused on Kalindaqdaq Masala which is themed on religion. Descriptive qualitative approach is used in this research to find out the Islamic Values in Kalindaqdaq Masala. There were 6 data which have been analized. The data showed that the order to perform Shalah in Islam is clearly implied in Kalindaqdaq Masala. This Research also showed that Kalindaqdaq Masala used as a media to spread the Islamic Values in West Sulawesi.
\end{abstract}

Keywords: Kalindaqdaq, Kalindaqdaq Masala, Islamic Value, Shalah Five times a Day, Afterlife.

How to cite: Marliana, R., \& Fachruddin, ATC. (2020). A Descriptive Qualitative Research: Islamic Values in Mandarese Oral Literature (Kalindaqdaq Masaala), ELS Journal on Interdisciplinary Studies in Humanities, 3(4), 582-589. DOI:

https://doai.org/10.34050/elsjish.v3i4.12287

\section{Introduction}

As one of big countries in the world, Indonesia is blessed with cultural and ethnic diversity. Some ethnics in Indonesia that has cultural inheritance which has been became an object of cultural studies such asBuginese, Javanese, Dayak, Sundanese, Balinese, Batak, Mandarese and many more. The diversity of ethnics groups in Indonesia is accompanied by the diversity of language and traditions. Sulawesi Barat Province also has some ethnic groups that live in, but the biggest ethnic groups is Mandarese. According to The Central Bereau of Statistics of Indonesia, the number of societies in West Sulawesi Province is 1.282 .180 and $49.15 \%$ are Mandarese.

Indonesia has many local literary works from vary tribes. Each region in Indonesia has their own literary works. Literature has many genres like novel, short story, prose, poetry, folklore and many more. Literature in various genres provides social and moral messages that ideally carry equality and peace in countries hindered by various ethnic groups (Rahman \& Weda, 2018) There are many local literary works in Indonesia, like Bekesah Puspakrama from Sasak

${ }^{12}$ Sekolah Tinggi Agama Islam Negeri Majene, Indonesia. 
community,I La Galigo from South Sulawesi, and Kalindaqdaq from West Sulawesi.Kalindaqdaqis local literary work that very popular in in mandarese community in West Sulawesi Province.Kalindaqdaq poetry is used by most of the society which is spread across Mamuju, Majene, and PolewaliMandar Regency.

Adawiah \& Srimusdikawati (2019) stated that Kalindaqdaq is categorized as old poem, and today its only perform in special occasion. Heretofore, mandarese could listen kalindaqdaq in vary cultural rituals, but momentarily, it only performs in some rituals like mappatamma' (a celebration ceremony after completely reciting Holy Al-Qur'an), and Pammacca (tradtitonalself-defence performance). The ritual like wedding ceremony infrequently performs it. Hence, at this time, many young mandarese do not comprehend how to compile and performed kalindaqdaq.

Kalindaqdaq categorized as local literary work and oral literature. As Bodi (2013) stated that nobody knows the authors of Kalindaqdaq. As oral literature, kalindaqdaq only transmitted orally and not in written form. Bodi in Adawiah \& Srimusdikawati (2019)explain that Kalindaqdaq formed by two words, 'Kali' means discover and 'daqdaq' means heart. So, the definition of kalidaqdaq is all the feeling and thought from the heart and it is expressed and uttered with the figurative speech. Kalindaqdaq itself use mandarese language, the local language of mandar tribe as media. Not only as ethnic identity, local language has function for inter-ethnic communication (Rahman, 2018)

Kalindaqaqform is peculiar with other traditional poem in Indonesia. As Yasil \& Darwis (2017) described that the Each stanza in kalindaqdaq consist four lines, which the first line consists of 8 syllables and the second line has only 7 syllable, the third and fourth line consists of 5 and 7 syllables. In the term of the kalindaqdaqusers, it can be divided into KalindaqdaqNanaqeke (kids), KalindaqdaqTomanetuo (teenager), and KalindaqaqTomabubeng (Adult). Moreover, in term of the theme, Kalindaqdaqdivided into seven themes, they are:Kalinndaqdaq humor (KalindaqdaqPangino), satire (KalindaqdaqMattedze), social critics (KalidaqdaqPappakaningaq), education (KalindaqdaqPipatudzu), religion (KalindaqdaqMasala), patriotism (KalindaqdaqPettomuaneang) and romantic (KalindaqdaqTosipomongeq).

Literary works has some functions; one of them is to give the moral lesson. Peels (2020) explained that literature provides knowledge and understanding, promotes insight, embodies knowledge and understanding, gives us new perspectives, and opens up windows on the world. The view of literary works has moral or epistemic values, called cognitivism or humanism. Literature also can be a source of learning for the readers (Rahman et al., 2019) Kalindaqdaq, as literary works, reflects values, knowledge, norms and ethics that extracted into local wisdom. Kalindaqdaqalso plays its social role such as mediating the social interaction among Mandarese, educating and entertaining. (Adawiah \& Srimusdikawati, 2019).

The good literature work can promote new insight to the reader or to the hearer. Kalindaqdaq as well reflects the values that can educate the hearer.Some researchers have analyzed kalindaqdaq from different 
perspective. Adawiah \& Srimusdikawati (2019)focused on the patriotism theme in kalindaqdaqpettomuaneang. Yasil \& Darwis (2017)analyzed the language style in kalindadqdaq, which he used the stylistic approach to analyze the language style in kalindaqdaq. In this study, the researchers will focus to analyzed kalindaqdaqmasaala, the religious theme of Kalindaqdaq.This kalindaqdaq contains Islamic values such as, syahadat, perform five times shalah a day, zakat, shaum and perform hajj. Kalindaqdaqmasaala aims to teach the Muslim community in Mandar tribe about the core value in Islam, especially the five pillars in Islam. It can be easier for them to know all this Islamic pillar by hearing the literary work KalindaqdaqMasaala.The researchers focusedto find the Islamic value, especially the second Islamic pillar which is shalah as reflected in KalindaqdaqMasaala.

\section{Method}

This study used descriptive qualitative method. The qualitative research is refers to research about persons' live, behavior, stories, but also organizational functioning, social movement or interactional relationship. (Strauss \& Corbin, 1990). The researchers used descriptive qualitative method by compiling or classifying, analyzing and interpreting the data. The study focused on the KalindaqdaqMasaala.In collecting the data, the researchers attended some cultural event like mappattamma in PolewaliMandar. The researchers gained 6 kalindaqdaqmasaala. All the data were recorded and transcribed then translated into English. The data were analized and interpreted to comprehend the value of kalindaqdaq, particularly the order to pray five times a day. The researchers also took some supporting data from the Holy Qur'an, various journals and books to strengthen the results.

\section{Finding and Discussion}

Islam is a religion that has many followers in West Sulawesi Province. According to Central Bereau of Statistics of Indonesia., the amount of Muslims in West Sulawesi are 957.735 from total 1.158.651 societies, and most of them are Mandarese ethnic. It is the reason thatkalindaqdaq has a special position in the Mandarese society. One of the theme of kalindaqdaq is KalindaqdaqMasaala which focused in religious theme. KalindaqdaqMasaala aims to teach mandarese society the monotheism of one Allah almighty(Darmawati \& Sahabuddin, 2019). Islamic values are explained clearly in KalindaqdaqMasaala, one of the value is the order to perform Shalat five times a day.

The researchers compiled the kalindaqdaqmasaala from some ritual performances. Moslem in Mandar tribes believe that if they obey and apprehend the values of Islam, they have to follow the five pillars in Islam. One of them is five times prayers a day as reflected in kalindaqdaq below:

Data.1

labandimikkeqdeqna,

Di batangalebeu,

Tappadiala, 


\title{
Sambayanglimawattu.
}

\author{
"After I believed it, \\ And prepare to obey, \\ I also established, \\ Five time prayers a day."
}

The data 1above shows the hearer that when a people believe in Islam, they should obey all the rules in Islam including to perform five times prayers a day. Itis also mentioned many times in different form of kalindaqdaq.The order to performshalah five timesa day also mentioned in holy Qur'an (moslem's holy book), for example in Al Baqarah Verse 43 "Establish prayer, pay almstax, ${ }^{1}$ and bow down with those who bow down".(Kementerian Agama, 2012)

In the data 2 and 3 below, shows that the mandarese society that mostly moslem, also believe in the preparation to have a happiness after life. One of the preparation is to perform Shalat five times a day as illustrated in the kalindaqdaq below:

\author{
Data.2 \\ Parriqparriqisambayang \\ Ditallappasnawattu \\ Sigaitowaq \\ Diolo tong matemu \\ "Endeavor to pray, \\ Before time passes \\ Repent quickly, \\ Before you die."

\section{Data.3} \\ Passambayangmoqodaiq, \\ Pallimawattumoqo, \\ lamotuqu, \\ Piwongang di aheraq.
}

"May you pray,

At the very least five times a day and night, 
Because that's what it is,

The supplies brought to the afterlife"

As Moslems believed in life after death which portrayed also in holy Qur an Surah Al A'laa verse 17, "even though the Hereafter is far better and more lasting", (Kementerian Agama, 2012)moslems should prepare and effort to gain happiness in the day of ressurrection. One of the effort is to perform shalah as moslem daily basis. This faith also shows in mandarese community which is represented in kalindaqdaq masaala. For example, in data.3 line 4 "Piwongang di aheraq./The supplies brought to the afterlife" shows that the function of shalah as supplies to be brought in the after life. So, it means that to gain happiness in the after life, moslem in mandarese are taught to perform five time shalah in a day and night. It also shows in data.2 in line 1 and 2 "Parriqparriqisambayang//Ditallappasnawattu / Endeavor to pray//Before time passes" which mean moslems should conduct shalah on time in their whole life before they pass away.

In Islam, it is only God The Almighty who decides when a person dies, they will stay in their graves until Yawm al-din, the Day of Judgement. On that day, they will be raised from their graves and brought before Allah and judged on how they lived their earthly lives (Mutahhari, 2020).

In the data 4, 5 and 6 below, shows that the mandarese society believe that shalah is the way to prepare good supplies in grave. One of the preparation is to perform Shalat five times a day as illustrated in the kalindaqdaq below:

Data.4

\section{"Apaamopambalinna \\ Pettuleqna I Mukkar \\ Andianglaeng \\ Sambayang Lima Wattu}

"What it is the answer,

The question of the Angels Munkar,

No other,

But five times prayer a day."

In data.4 line 1 and 2 explain about the question of Munkar Angel and in line 3 and 4describe that prayer as a way of answering the Munkar angel's question in the realm of the Grave. This is supported by Hadith of Prophet which reported by Abu Huraira "The first action for which a servant of Allah will be held accountable on the Day of Resurrection will be his prayers. If they are in order, he will have prospered and succeeded. If they are lacking, he will have failed and lost. If there is something defective in his 
obligatory prayers, then the Almighty Lord will say: See if my servant has any voluntary prayers that can complete what is insufficient in his obligatory prayers. The rest of his deeds will be judged the same way."(AtTirmidhī, 892)

As one pillars of Islam, perfoming Shalah regularly can safe Moslem from punishments in afterlife. Other obligation that must conduct by moslems is do charity, for example help the poor people. Its implied in the kalindaqdaq masaala below :

\author{
Data 5 \\ Amal di annaqsambayang \\ Anna sukkuqrakkeqmu \\ Na mappallappas \\ Sara di lalangkuqbur \\ "Only charity and prayer,
And your perfect piety
That will release
Tribulation in the grave."
}

In line 1 in the data 5 mention "Amal di annaqsambayang",the word"amal" means charity and sambayang means "shalah" or prayer. It can be concluded that a good moslem should conduct both of them. In line 3 and 4 explains if moslem do charity and shalah regularly will help the avoid all the pusnishment in grave, or in afterlife.

The afterlife for moesliem is described on surah an Nur verse 25, "On that Day, Allah will give them their just penalty in full, and they will 'come to' know that Allah 'alone' is the Ultimate Truth."(Kementerian Agama, 2012) The phrase on that day means the afterlife. Shalah become moeslims provisions in the afterlife. In surah an Nur is also mention that moeslims shalah will be acknowledge, "...Allah will give them their just penalty in full...." Shalah will also be the source of light and convenience in afterlife. It's described as well in the data 6 .

\title{
Data 6 \\ Sambayang di tiatuqu \\ Na dipajarisulo \\ Na dipajari \\ Tappere di kuqburta
}

"Prayer that is 


\section{Which will be used as a torch of light \\ And will also be made}

As mat in the grave.

The data 6 above implied that if moslem conducted shalah regularly, it can help them to get convenience in aftrelife. It is explained on the prhase "Na dipajarisulo//Which will be used as a torch of light" and in the line 3 and 4 "Na dipajari/Tappere di kuqburta//And will also be made/As mat in the grave". These phrases implied an amenities.

\section{Conclusion}

As an oral literature in West Sulawesi, Kalindaqdaq has various themes such as Kalinndaqdaq humor (Kalindaqdaq Pangino), satire (Kalindaqdaq Mattedze), social critics (Kalidaqdaq Pappakaningaq), education (Kalindaqdaq Pipatudzu), religion (Kalindaqdaq Masala), patriotism (Kalindaqdaq Pettomuaneang) and romantic (KalindaqdaqTosipomongeq). This research focused on Kalindaqdaq Masaala which explain and describe about Islam Religion especially the order to perform shalah five times a day. It also explained the benefit that moeslims get in performing shalah. This Kalindaqdaq Masaala also explaine the portrait of afterlife in Islam. It is concluded that Kalindaqdaq Masaala used to spread Islamic Values to Madarese Community in West Sulawesi Province.

\section{References}

Adawiah, R., \& Srimusdikawati. (2019). Contextualization and Entextualization Mandarese Patriotism in Kalindaqdaq Pettuomuaneang Performance. Jurnal Adabiyah, 19(1).

At-Tirmidhī, A. `Isa M. (892). Jāmi’ at-Tirmidhī (p. 413).

Bodi, M. I. K. (2013). Kalindaqdaq Masaala dalam Bahasa Mandar. Zadahaniva Publishing.

Darmawati, B., \& Sahabuddin, C. (2019). Kalindaqdaq a Medium od Mandarese Character Building. Proceedeing of the 28th International Conference of Literature: "A Source of Wisdom," 28.

Kementerian Agama, R. I. (2012). Al-Quran dan Terjemah New Cordoba (1st ed.). Syamil Quran.

Mutahhari, M. (2020). The Resurrection. Al Islam.Org. https://www.alislam.org/eternal-life-life-after-death-ayatullah-murtadhamutahhari/resurrection

Peels, R. (2020). How Literature Delivers Knowledge and Understanding, Illustrated by Hardy's Tess of the D'Urbervilles and Wharton's Summer. British Journal of Aesthetic, 04.

Rahman, F. (2018). The Constraints of Foreign Learners in Reading English Literary Works: A Case Study at Hasanuddin University. Journal of Arts and Humanities, 7(2), 01. https://doi.org/10.18533/journal.v7i2.1327 
Rahman, F., Amir P., M., \& Tammasse. (2019). Trends in reading literary fiction in print and cyber media undergraduate students of hasanuddin university by. International Journal of Education and Practice, 7(2), 66-77. https://doi.org/10.18488/journal.61.2019.72.66.77

Rahman, F., \& Weda, S. (2018). Students' Perceptions in Appreciating English Literary Works through Critical Comment: A Case Study at Hasanuddin University and Universitas Negeri Makassar. Asian EFL Journal, 20(12), 149-172.

Strauss, A., \& Corbin, J. (1990). Basic of Qualitative Research : Grounded Theory Procedure and Techniques. Sage Publications.

Yasil, S., \& Darwis, M. (2017). Language Style on the Kalindaqdaq Poem (Introduction to Stylistic Study of Mandar Regional Literature). International Journal of Science and Research (IJSR), 6(9). 